\title{
Stories of an Era Not Yet So Very Remote: James Cowan in and out of New Zealand History
}

\author{
CHRISTOPHER HILLIARD
}

\begin{abstract}
This essay provides a critical overview of James Cowan's writings, his methods, and his publishing history - chiefly in New Zealand but also in Britain and Germany. Cowan was more of an anthologist than a synthesizer. His significance for popular historical consciousness lies in his small stories rather than his larger moral narrative of the New Zealand Wars and their implications for "race relations." In his historical journalism, Cowan constantly reminded Pākehā that they did not live in a land without a past, and that the exciting colonial past was tantalizingly close.
\end{abstract}

James Cowan dealt in stories of old New Zealand. ${ }^{1}$ You can see it in the titles of his booksHero Stories of New Zealand, Tales of the Maori Bush, Tales of the Maori Coast, Tales of the Maori Border - and in the way he described his research. Discussing an event in the New Zealand Wars, he told a fellow historian that he "obtained good narratives some years ago from two of the six or seven Maoris" who were there at the time. "Narrative" and "narrate" are words that recur often in Cowan's research notes and correspondence. ${ }^{3}$ He saw himself as a gatherer of narratives of a not-quite-vanished past as well as a storyteller in his own right.

Cowan's legacy as a dealer in stories has been significant for New Zealand history on two levels, the particular and the general. His books and the Cowan papers in the Alexander Turnbull Library are caches of detailed evidence that later historians have drawn on. Researchers involved in Treaty claims have made extensive use of Cowan's published and unpublished writings, and in his 1986 history of the New Zealand Wars, James Belich made it clear that Cowan's own papers underpinned his revision of Cowan and other interpreters of the wars. ${ }^{4}$ Cowan was also a teller of larger, more mythic stories about New Zealand and its past. He described a colonial period marked by adventure more akin to that of the American West than other frontiers of the British empire. In a newspaper piece about frontier Taumarunui, he mentioned reading "... one of those American magazines which specialise to a large extent in recollections of 'the old frontier' type":

Taumarunui was not shot-up periodically by belted and sombrero'd cowboys bristling with "six-guns". It "got its eddication in a peaceful kind of way." There were no Wild Bill Hickoks, no Crooked Kids . . . . Yet the Main Trunk line in Taumarunui's babyhood rejoiced in its own particular kind of-well, not wild lawlessness, but, say, casual indifference to the conventions of Queen Street, Auckland. $^{5}$

And he had a story about "race relations". Cowan's most frequently-quoted observation comes three pages into his two-volume history of the New Zealand Wars: "The wars ended with a strong mutual respect, tinged with a real affection, which would never have existed but for this ordeal by battle." "The draft version was more tentative: "In truth, the long wars ended with a strong mutual respect, tinged sometimes with a real affection, which assuredly would never have existed but for this ordeal by battle." ${ }^{, 7}$ Even the more emphatic final version was careful to posit respectful relations between Māori and Pākehā rather than undisturbed sunshine. As Jock Phillips has pointed out, the idea that the wars had a racially 
amalgamating effect had been articulated before Cowan, beginning right after the wars with the memorial to the Māori dead in St John's Church in Te Awamutu. ${ }^{8}$ But as Phillips's and Chris Maclean's book on war memorials shows (albeit indirectly), this view did not become Pākehā conventional wisdom in the way that comparable statements about the First World War did later. ${ }^{9}$ Or rather, the idea of the New Zealand Wars as a crucible of respectful race relations became amplified only later, as it could be assimilated to memories of the First World War and the accomplishments of the Maori Battalion in the Second. At the time Cowan wrote his official history, the lesson he drew from the wars was one nurtured chiefly by survivors of the era. The ideal of respect forged through war was one that appeared to be embodied by older Pākehā whom Cowan was close to and respected enormously, such as Gilbert Mair and Thomas Porter-veterans of the kūpapa campaigns, members of the "native affairs" apparatus after 1872, connoisseurs of Māori legends, men with Māori wives or lovers. If Cowan's famous sentence now has the ring of a cliché from the age of high imperialist militarism, it was not a cliché at the time. He could not expect his readers to take it for granted.

In my own writings about Cowan, I have placed a lot of weight on this summary judgement, what I called his metanarrative of New Zealand history. ${ }^{10}$ Some second thoughts may be in order. The fact that this is the most quotable sentence in the wars volumes does not make it the key to them. Cowan's detailed accounts of the campaigns and sorties do not lead inexorably to the conclusion about race relations. When he writes about the campaigns against Te Kooti, he mentions the esteem the Mair brothers had for their kūpapa allies, but this is not the same as respect for the enemy. The chapters on the War in the North conclude with the observation that "Ngapuhi have ever since 1846 been loyal friends of the whites", and that generations later northern iwi "sent over six hundred of their young men to join the contingent which fought so well on Gallipoli in 1915". But Cowan explains the loyalty of the northern iwi in terms of the peace settlement - the absence of a crushing defeat, the lack of confiscationsnot in terms of the experience of Ngāpuhi fighting British soldiers. ${ }^{11}$ The account of the Waikato War in Cowan's history necessarily does not end in a basis for respectful race relations in the future; and even if the white participants had come to respect their opponents, many of them remained in the British army and left New Zealand.

Moreover, to place a lot of emphasis on Cowan's metanarrative of respectful race relations might be a misreading of the kind of writer he was. David Hall of the Centennial publications staff meant to be cutting when he described Cowan's Centennial volume Settlers and Pioneers as a "wickedly episodic bundle of papers," but whether or not you think it wicked, it is hard to dispute that most of Cowan's books were bundles of more or less discrete stories. ${ }^{12}$ The books whose titles I mentioned a page or so back, Hero Stories and the like, were overt anthologies, but the other books, even some of the biographies, also have the episodic looseness of an anthology. With Cowan, the details matter much more than the generalizations; the books are driven by a set of interests and assumptions, but not by a thesis. Perhaps if we pay attention to those details, and the interests and assumptions beneath them, we might arrive at a better understanding of Cowan's place in New Zealand cultural history.

This essay is meant as an introduction to Cowan's work and as a reconsideration of my earlier discussions of him. ${ }^{13}$ It is based on Cowan's published work and the Alexander Turnbull Library's holdings on manuscript papers as they stood until recently. The acquisition and cataloging of a new trove of Cowan's papers, which Ariana Tikao describes in this issue, will prompt new approaches to Cowan that go far beyond the ideas I sketch here.

Cowan firmly believed that the authentic taste of the past - he was good on tastes and smellscame from personal memories. Though he identified himself with the world of journalism, and made much use of old books, he could be leery of written documents as historical sources. He routinely gave more credence to oral testimonies than written accounts. More unusually for the 
time - and not just for his time - he sometimes trusted Māori oral narratives over Pākehā written texts. ${ }^{14} \mathrm{He}$ had no time for objections that memories were subject to distortion and axegrinding. What he saw as the directness of oral testimony trumped the second-hand quality of most written accounts, and especially of the "hearsay" of newspaper coverage. As we shall see, the relation between interviewer and interviewee lent oral testimony an affective authority.

Cowan's success as a writer of historical books and newspaper articles hinged on his ability to interview Māori people, especially kaumātua in places remote from the main centres. This was not the rarest of skills for a Pākehā born in 1870, as the size of the Polynesian Society's active membership indicates. However, exercises in "Māori history" undertaken by local ethnologists tended to stop before the arrival of the British: most Pākehā researchers were looking for ancestral knowledge rather than eye-witness testimony to events. Cowan's focus on the conflicts of the 1860s and 1870s, and the tense interactions of the following decades, was distinctive. If there were other bilingual historians investigating the recent past, they did not publish their findings anywhere near as much or as prominently as Cowan did.

Many Pākehā who collected oral traditions worked for the Native Department or other state agencies or private businesses that brought them into regular contact with Māori people, such as surveyors' firms or legal practices. The diary of Ben Keys, a licensed interpreter retained by a Bay of Plenty law firm to track down owners of blocks of Māori land and secure their signatures on sales deeds, shows in detail how such work provided opportunities to collect tribal histories or learn about indigenous plants and animals. ${ }^{15}$ Visiting the beach at Maketu one afternoon in 1920, Keys decided to try to find out about any local knowledge or customs relating to shellfish. "I followed my usual practice of cottoning on to the oldest Native I could find and pumping information out of him. In this case it was a man of about 40 years, and he talked freely enough."16

Cowan himself had almost had a career in what Keys called "native work." Cowan grew up near Kihikihi, on a block of confiscated land. The family farm included part of the Ōrākau battle site. James's father had fought for the Crown in the Waikato War. ${ }^{17}$ In a letter from 1937, Cowan wrote of "the old farm and bush life in which I was reared in the seventies;

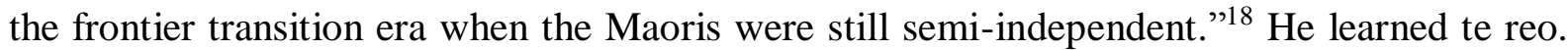
That, together with his results in the junior civil service exam, secured him an offer of a cadetship at the Native Department. ${ }^{19}$ He turned it down, evidently because his mother thought he was too young for the big city; within two years, he was living in Auckland as a reporter for the Star. ${ }^{20}$ The stories he elicited from Māori informants and wrote up for publication reflected this combination of skills - the skills of the journalist and those of the back-blocks cultural broker.

Cowan was accumulating stories of old New Zealand long before he published his first book. He told his paymaster at the Department of Internal Affairs, which commissioned his official history of the New Zealand Wars, that "this History is not merely the product of the short period I was under Government engagement on contract; it embodies the result of many years' work, practically a life-time of note-gathering on the subject." 21 A life-time of notegathering was also a life-time of travelling round New Zealand. Cowan's career was a peripatetic one before he and his second wife had children in the late nineteen-teens. He lived and worked in more different regions than most New Zealand writers of note- - he was a salaried journalist for years in Auckland and Christchurch as well as an employee of the Department of Tourist and Health Resorts and freelance writer based in Wellington. The research for the wars book also involved a good deal of travel. Cowan told his prospective employers at Internal Affairs, "In many instances there are veterans, either European or Maori, living close to the old battle-grounds. These would be interviewed. . . It is important that the Maori side of the Wars be fairly represented, and I would interview reliable Natives who could throw light on disputed 
events. As I speak and write Maori I would be able to gather this information at first hand. I have already obtained much useful data from Maoris."22

Cowan's research trips involved retracing the steps of historical actors as well as interviewing them. Over two days in January 1921, Cowan and the elderly Gilbert Mair were guided by "an Urewera man named Te Roku" along the route of Colonel St John's march up the Whakatāne River. ${ }^{23}$ The often-reprinted photograph of Mair by the graves of Captains Travers and White, comrades in the Ruatāhuna campaign of 1869, was taken by Cowan a month later. ${ }^{24}$ Cowan made a point of telling the Department of Internal Affairs that he would take his camera with him on his travels. ${ }^{25}$ The published volumes and the Turnbull's collections include a number of the photographs he took, both of places and informants.

Visiting battle sites was important, Cowan argued in his proposal for the wars volumes, because it would mean he could "make topographical descriptions so precise as to enable readers and visitors to identify the battle-grounds readily." ${ }^{26}$ One of Cowan's supporters, T. W. Leys, who was co-owner of the Auckland Star, lobbied the Minister of Internal Affairs to go ahead with the official history project for cognate reasons. The subject needed to be researched before the last veterans died, he said; and the landscape too was on the verge of changing beyond recognition. "Many of the forests through which our European and Native contingents pursued the rebel forces have been cleared, the old redoubts levelled and ploughed, and even the tradition regarding their locality is lost." ${ }^{27}$ The published volumes include a great many maps or plans of battle sites drawn by A. H. Messenger, a draughtsman born into "a pioneer Taranaki family," a founder of what is now Forest and Bird, and, many years later, author and illustrator of Children of the Forest. ${ }^{28}$

Cowan's sense of place and attention to topographical detail are one reason for his enduring appeal. Michael King recalled his excitement on discovering Cowan as a ten-year-old in 1955:

I was living near Paremata on the Pauatahanui arm of the Porirua Harbour. I knew the harbour well ... . In Volume I of The New Zealand Wars I found a detailed account of what had happened militarily in the neighbourhood in 1846. Most important to me, the account was supplemented with maps, photographs and descriptions of combat scenes that enabled me to pinpoint and to stand on each site. This was my first encounter with the experience described in the hackneyed but wholly apt expression about history coming alive. I felt the presence of people who had gone before, I saw them in a kind of Arthurian world that was not in Camelot but literally on my own doorstep. ${ }^{29}$

Cowan would have been pleased. He wanted to make New Zealand's past come alive to generations who had grown up in a settled colony, in country where the redoubts had been levelled and ploughed and the forests where skirmishes had taken place had been cut down and turned into pasture. In a passage that was deleted from the published version of The New Zealand Wars, Cowan reflected:

... the translation of the country from a war-ravaged wilderness of bush, fringed with a few precarious settlements, to a peaceful dominion not only of great wealth but of some influence in the world's councils, has been accomplished in a period so short that it excites wonder among all who give a thought to our history. There are those still living who saw the first campaigns in which British redcoats met Maori toa in a bayonet charge; there are many who can recall their nights of sentry duty in Auckland city against a feared Kingite invasion... We who are not yet old have seen blockhouses and redoubts, garrisoned by blue-uniformed [i.e., colonial] soldiers studding the Maori frontiers, each with the British ensign on its tall flagstaff in token of the protecting arm that in reality did not extend beyond rifleshot of its 
walls. Many a white veteran and many a Maori can still tell of battle adventures, of stormings and defences, of daring scouts and man-huntings, in country that is now disturbed by nothing more alarming than the railway engine's whistle or the motor horn of the well-off dairy farmer. ${ }^{30}$

The way the recent past could seem uncanny in its combination of difference and closeness was a theme Cowan returned to in his 1936 book of South Pacific tales, Suwarrow Gold. New Zealand's past was not the only patch of history that excited wonder, or at least a feeling of disorientation. In Suwarrow Gold, it was the sailors and the rhythms of "the old schooner days," before steam had altogether replaced sail, that had vanished not long before: the "old traders and navigators" were "the heroes and ruffians of an era not yet so very remote." ${ }^{31}$ Of Hans Tapsell's life, Cowan remarked, "The incidents of this biography have almost the air of romance. It is like opening an old volume of history to obtain from a living source the personal adventures of one who[s]e reflections extend into the past century." 32

It is as if there was a relation to the past that was peculiar to the condition of life at the edge of empire. This concern with time and change, with the dislocating speed of the colonial past, makes Cowan's approach to history and memory distinctive among New Zealand historians of the first half of the twentieth century. His belief in oral history, in the importance of preserving memories and words that survivors of "an era not yet so very remote" used to describe their experiences, was more complex than the conventional commitment of local history societies, and published historians such as Robert McNab and T. Lindsay Buick, to conserve the records of the past and commit them to print with minimal editing or synthesizing. ${ }^{33}$

Cowan was doing something more, but he was certainly committed to preserving the narrative traces of what he called the pioneering period. And the need to get the memories of Māori and Pākehā veterans of the New Zealand Wars on record was one of the main reasons the project went ahead. Urging the under-secretary of Internal Affairs to support the proposed history, J. Allan Thomson of the Dominion Museum said that it was "greatly to be regretted that no historical investigator is at present working on the history of the Maori wars, for such a person ... could by means of leading questions obtain from actors in the scenes of war much additional information which in a few years will otherwise become lost." ${ }^{34}$ Like many local historians who sought to memorialize the pioneers of their district, Cowan regarded recording as an act of honouring. ${ }^{35}$ And getting an informant to talk about their experiences often required Cowan to win their trust. In his notes on the life of one of his informants, Peita Kōtuku, Cowan says that when he first met him, Kōtuku was hesitant and shared only a few details; when they met again later, he opened up and answered many questions. ${ }^{36}$

This meant that Cowan had an emotional investment in the testimony of his informants. When the antiquarian Horace Fildes disputed Cowan's account of Ōrākau, which was based on oral testimony, Cowan accused him of "damned impertinence" in questioning William Mair's conduct by questioning Cowan's version of it:

No one living knows the facts of Orakau as I do ... My friends from boyhood Te Huia Raureti and Tupotahi — men related to Rewi-faced Mair at a few yards' distance ... at Orakau ... \& heard \& saw the whole of the Korero with their fellow defenders.... I am the only man who went to the trouble to take the evidence of the actual participants. ${ }^{37}$

Cowan said that his best authorities were "'human documents,' not other people's books". He believed these "human documents" lent him authority in the expansive sense as well. ${ }^{38}$

When re-telling these stories himself, Cowan often took pains to retain their yarning quality. In his volumes of what we might call non-fictional short stories-Tales of the Maori 
Coast and so on - he often described how he came to hear the story he was about to relatewhere he heard it, the old man who told it to him. This was a common device in the short stories carried by a great many magazines produced in the British empire in the late nineteenth and early twentieth centuries, from the comfortably middle-class Strand, home of Sherlock Holmes, to the penny weeklies bought by working-class readers. ${ }^{39}$ Such fiction was often described as "the magazine story," a genre in its own right. ${ }^{40}$

New Zealand newspapers provided openings for historical sketches and for articles that traded on familiarity with Māori people and indigenous forms of knowledge. The "nature notes" that were a staple form of filler could be enhanced by "traditional" learning about birds, fish, and plants. Nature notes were one of the genres that Cowan's father-in-law Henry Stowell, aka Hare Hongi, tried his hand at as he made the transition from "native interpreter" and language teacher to journalist and pundit. Stowell's papers include a collection of typed nature notes about the funny ways of owls and eels ready to be dispatched to newspaper editors. ${ }^{41}$ Stowell was also approached by other freelances who had nothing like his cross-cultural expertise. In 1930 James A. Stevens of Palmerston North wrote to Stowell asking him the Māori name of a species of caterpillar. Stevens was doing a nine-month series of daily "Maori Nature Note[s]" for a group of newspapers. ${ }^{42}$ A few years later, Stevens was trying to churn out a brief "Passing Maori Memory" for newspapers every day for six months. ${ }^{43}$ That Stevens was hoping to produce more than a hundred passing Māori memories hints at how large a part of New Zealand popular culture was the genre of the passing-of-the-old-time-Māori story (and its cognates in the visual arts, such as C. F. Goldie's portraits). Many of Cowan's own newspaper contributions have elements of this genre, with their descriptions of the aged Māori settling down to tell the story now being passed on to the reader - though, as I have suggested, Cowan's sense of the relationship between past and present was more uneven than that implied by a straightforward "passing" of an old Māori order.

Cowan sent historical articles to many publications, perhaps above all to the Auckland Star, where he had once been an employee. He also did a good deal of descriptive and more or less historical writing for publicity agencies, initially as a freelance and then, between 1903 and 1909, as a salaried employee of the Department of Tourist and Health Resorts. Cowan continued to take commissions for tourist publicity, such as a pamphlet on Rotorua as the "wonderland of the world" for the Rotorua Morning Post and Romance of the Rail for the Publicity Branch of New Zealand Railways. The railways department was an important source of income. One of Cowan's regular outlets in the 1930s was the magazine the department produced for a wide readership. The official purpose of the New Zealand Railways Magazine was to promote domestic tourism by train, but the publication doubled as a forum or playground for Wellingtonbased journalists and writers. ${ }^{44}$ Cowan was so identified with the voice of the Railways Magazine that a hostile report on his Centennial survey complained of its "Railways Magazine rhetoric." 45 The Railways Magazine carried a long series by Cowan entitled "Famous New Zealanders," which acquired some of the standing of a reference book before the publication of the first Dictionary of New Zealand Biography a few years later.

Surprisingly, the "Famous New Zealanders" series was not reissued in book form. Because Cowan's livelihood depended on publication in newspapers and magazines, his books tended to include material that had already done at least one tour of duty in a newspaper or magazine. He built up an extensive collection of stories that he could recycle in newspapers on appropriate occasions (sometimes newspapers recycled them without his permission), ${ }^{46}$ or reuse in a book without much re-writing. He would add a bridge or remove background material that had been necessary in a stand-alone piece but which was now superfluous in the context of the book. These days we know Cowan primarily through his books, but the books were secondary to his livelihood. In a revealing letter after her husband's death, Eileen Cowan 
remarked that "The real reason for his books was to embody all his writings in a permanent form." 47

There was money to be made from publishing books in New Zealand in the 1920s and 1930s, but not very much, and little of it went to the author. Both Reed and Whitcombe \& Tombs could act like de facto vanity publishers, asking the author to bear some or all of the costs of production and distribution. ${ }^{48}$ As a popular author, Cowan does not appear to have been treated that way, but in 1934 it could nevertheless be said that he "had never made any money out of his historical books." This was the claim made by a deputation from the writers' group PEN that asked for a civil list pension for Cowan as his health deteriorated and his freelance income dwindled in consequence of the depression. ${ }^{49}$ The request was declined, notwithstanding the support of Labour MPs including Peter Fraser. After Labour's election victory the following year, PEN tried again, and Cowan was granted an annuity of $£ 100$ from the beginning of $1936 .{ }^{50}$ This was considerably less than a labourer employed full-time earned in a year. ${ }^{51}$

Cowan's earnings were circumscribed by the small New Zealand market. He did, however, sell some work to overseas periodicals, including the London-based Wide World Magazine and New York's Adventure as well as the Sydney Bulletin, which almost counted as a domestic publisher for ambitious New Zealand authors. ${ }^{52}$ The only book of Cowan's that was published outside New Zealand was Suwarrow Gold. Very much an Auckland book, most of its stories were relayed to Cowan by the crews of schooners that used to dock in Auckland. ${ }^{53}$ (The book's working title was "Schooner Men.") ${ }^{54}$ The prose is distinguished by moments of disciplined grace ("An ocean of fiction washes the islands of the Pacific"). ${ }^{55}$ Suwarrow Gold may have been the only book of Cowan's to be professionally edited, as local publishers invested very little in sharpening up the manuscripts they accepted. Suwarrow Gold was published by the distinguished London firm of Jonathan Cape. Cowan told the Wellington literary gadfly Pat Lawlor that he knew his friend would "be pleased I have 'butted in' to the London publishing world at last" - though he took care to add that Suwarrow Gold was "the first book I have sent to a London publisher." ${ }^{56}$ Cowan's friend Alan Mulgan prepared a press release for the Australasian market, declaring that this was "the first book by Mr. James Cowan to be issued in England, and its publication is therefore an event in New Zealand literary history." ${ }^{57}$ As Dennis McEldowney observed, Cape's acceptance of Suwarrow Gold "must have been a highlight in his long career... He kept all the correspondence with Cape, but not with local publishers." 58

Cowan initially tried to sell his manuscript to the Australian publishers Angus and Robertson. ${ }^{59} \mathrm{He}$ described his ambitions in a letter that he may not have ended up sending: "I have had a number of books published in New Zealand; but this is the first I have offered to an Australian publisher. I am anxious to obtain a wider field than New Zealand offers, and have written this book with that end in sight." 60 Angus and Robertson had three readers look at the manuscript. Eventually they decided that the book was unlikely to pay its way in Australia, but that if Cowan found a British publisher they would be happy to "to push its sale here." ${ }^{\circ 1}$ Cowan found a British publisher when he met Jonathan Cape himself as the latter toured New Zealand at the beginning of $1935 .{ }^{62}$ Cape wrote to Cowan several months later asking why he had not yet received the manuscript. ${ }^{63}$ Cowan had been suffering from a long illness, and it was December that year before he submitted the typescript, with the title changed from "Schooner Men" in case "the mention of gold has some magic for buyers." 64

The book had good reviews in Britain - in The Times, the Times Literary Supplement, the popular middlebrow literary magazine John o'London's Weekly — but the reviews did not translate into large sales. ${ }^{65}$ The book sold respectably in its first few months. The royalty statement Cape sent Cowan at the end of December 1936 recorded 562 sales. The majority of these, 342 , were sales of the British edition, which retailed for $7 \mathrm{~s} .6 \mathrm{~d}$. By the time of the next 
statement, six months later, the volume of sales was much lower, and the majority of them111 out of 132-were of the cheap "colonial" or "overseas" edition, which was priced at 3s. $9 \mathrm{~d} .{ }^{66}$ Colonial sales accounted for the majority of the modest number of sales over the next few years. ${ }^{67}$ Cowan earned a ten per cent royalty on both kinds of edition: obviously, he earned much less from sales in New Zealand than from sales in Britain. ${ }^{68}$

So Cowan had not butted very far into the British market. When he offered Cape three more books while Suwarrow Gold was in press, Cape replied that he would rather wait and see how that book sold before committing to more; then, rather than leave things hanging, he explicitly rejected The Sword of Von Tempsky, Knocking About, and Wild Sanctuaries, which remain "lost" books in the Cowan canon. "I don't think that any of these books would be likely to command a wide sale if published here," Cape said. ${ }^{69}$ However, Suwarrow Gold still had a further, unexpected international success in store. After its publication in London, the book was picked up by the Leipzig firm of Wilhelm Goldmann, which published a German translation in $1938 .^{70}$ Goldmann paid $£ 25$ (minus ten per cent for the German agent, minus another ten per cent commission to Cape). The company paid in advance-_"a pleasing surprise," Cowan said. ${ }^{71}$

Goldmann had built a successful publishing house primarily on the strength of his detective fiction list - he was the German-language publisher of the British bestseller Edgar Wallace. Early in 1937 Goldmann found himself under pressure from the Reich Chamber of Literature, and in particular the bureau that regulated "entertainment literature." After initially trying to keep on side with the Nazi authorities by jettisoning books by Jewish authors but otherwise doing business as usual, Goldmann abandoned "entertainment literature" such as detective novels and concentrated on less troublesome genres, which, somewhat surprisingly, included history. ${ }^{72}$

The descriptions of other books published by Goldmann at the same time indicate that the market they envisaged was one of German readers interested in the history and prospects of places that at different times had been part of the imperium of European powers. Wilde Südsee by James Cowan sat alongside studies of contemporary Japan, China and Africa; a book on "Egypt's path to freedom" and another on the "Arab world"; several books on British imperialism and another on Britain, Italy, and the Abyssinian war of 1935; and volumes on Germany's lost colonial empire, which of course included some of the Pacific islands that featured in Cowan's book. Goldmann also published a memoir of travels in the southseas by the writer and canoeing enthusiast Herbert Rittlinger. ${ }^{73}$ Thus Goldmann slotted Cowan's book into a list oriented toward imperial history and geopolitics, whereas the style of the original suggests that Cowan and his Anglophone readers and publishers conceived of the book as a collection of non-fictional Robert Louis Stevenson stories. Pitching it to Angus and Robertson, Cowan had described the book as "a series of real-life adventure stories." 74 Mulgan started his review in the Wellington Evening Post of Cowan's book of "true tales" with an anecdote about Stevenson, and the Times Literary Supplement reviewer similarly accepted Cowan's own characterization of the book as combining the poetics of south-seas adventure with the solidity of fact: "his true tales of the Pacific beat fiction." 75

We need more research on the fortunes of Cowan's work in American and British periodicals; but I would guess that when Wide World Magazine accepted Cowan's submissions, it was buying "entertainment literature"-non-fiction adventure stories. The British Empire and the United States constituted an immense and voracious market for true-life stories published in periodical as well as volume form. Those periodicals had to strike a balance between formula and variety, and there was an international readership for Māoriness and colonial intrigue in a setting less familiar than Africa or the Middle East. Film-makers, not just in New Zealand but also in the United States, gambled on the existence of such a market. The existence of those overseas audiences for representations of Māori life or colonial history is worth remembering, 
given how accustomed we are to thinking of stories like Cowan's and the appropriation of Māori culture in the context of Pākehā identity and the fostering of New Zealand patriotism.

This brings us back to the question I raised at the beginning. If we focus on Cowan the collector and teller of small stories rather than the Cowan who, on appropriate occasions, gestured at much more encompassing stories of New Zealand, how are we to think about his relationship to New Zealand culture more broadly? I am not suggesting that we ignore the big picture and luxuriate in the details. Rather, I want to suggest that the details help us get at the big picture more effectively than Cowan's explicit mission statements do. Here it may be useful to draw an analogy with Michael Billig's concept of "banal nationalism"-not coherent national identities or national ideals, but the humdrum national consciousness engendered by street names, flags, and other signs of nationhood that we might not notice all the time, but which help perpetuate a sense that the country around you exists, means something. ${ }^{76}$ If we think of historical consciousness in a similar way, Cowan's grand narrative of the New Zealand Wars may be less important than the fact that he constantly reminded younger Pākehā that they did not live in a land without a past — and that the exciting colonial past was tantalizingly close, "not yet so very remote." The extent of his output and the everydayness of Cowan's historical writing - the fact that newspaper readers would run across snippets about Ōrākau or Te Kootiprobably did more to engender an awareness of the past in New Zealand than any number of manifestos or ringing conclusions. Plenty of Cowan's contemporaries huffed and puffed that New Zealand had an exciting and distinctive history: but they did not provide directions so that readers could locate the traces of it for themselves on the shores of Porirua Harbour.

\footnotetext{
${ }^{1}$ The author wishes to thank Annabel Cooper and Ariana Tikao; the two anonymous referees for the Journal of New Zealand Studies; and all the participants at the James Cowan symposium at the Alexander Turnbull Library in February 2014.

${ }^{2}$ James Cowan to Horace Fildes, 16 December 1922, H. E. M. Fildes Papers, box 34, J. C. Beaglehole Room, Victoria University of Wellington Library (VUW).

${ }^{3}$ Further examples include James Cowan, "A Hauhau Warrior's Story: The Adventures of Peita Kotuku, Last Survivor of the "Rifleman" Escapees (Notes taken by J. Cowan, 23/2/21)," James Cowan Papers, MS-Papers-0039-41A, Alexander Turnbull Library (ATL); Cowan, "To Add Puketaukere Chapter: The Swordsman in the Swamp: An Incident of the Waitara War," undated typescript, Cowan Papers, MS-Papers-0039-42F, ATL; Cowan, "The Ohaeawai Battlefield: Rihara [K]ou's Narrative," Cowan Papers, MS-Papers-0039-41, ATL.

${ }^{4}$ James Belich, The New Zealand Wars and the Victorian Interpretation of Racial Conflict (Auckland: Auckland University Press, 1986), 16.

${ }^{5}$ James Cowan, "Old Taumarunui. Heart of the Hauhau Country," clipping from the Auckland Star, 5 June 1926, Cowan papers, MS Papers 0039-42C, ATL.

${ }^{6}$ James Cowan, The New Zealand Wars: A History of the Maori Campaigns and the Pioneering

Period, 2 vols. (1922-1923; repr., Wellington, 1983), 1: 3.

${ }^{7}$ James Cowan, "Chapter I: The Old Race and the New," n.d., Cowan Papers, MS-Papers-0039-42C, ATL. Italics indicate words not in published version.

${ }^{8}$ Jock Phillips, "War and National Identity," in Culture and Identity in New Zealand, ed. David Novitz and Bill Willmott (Wellington: GP Books, 1989), 97.

${ }^{9}$ Chris Maclean and Jock Phillips, The Sorrow and the Pride: New Zealand War Memorials

(Wellington: Historical Branch, GP Books, 1990).

${ }^{10}$ Chris Hilliard, "James Cowan and the Frontiers of New Zealand History", New Zealand Journal of History 31, no. 2 (1997): 219-33.

${ }^{11}$ Cowan, New Zealand Wars, 1: 87.
} 
${ }^{12}$ D. O. W. Hall, "Mr Cowan's Survey," 8 September 1939, Internal Affairs files (IA), series 1, 62/110/2, Archives New Zealand (ANZ), Wellington.

${ }^{13}$ Hilliard, "James Cowan," Hilliard, "Island Stories: The Writing of New Zealand History, 19201940" (MA thesis, University of Auckland, 1997; available online at

http://nzetc.victoria.ac.nz/tm/20scholarly/tei-HilIsla.html); Hilliard, The Bookmen 's Dominion: Cultural Life in New Zealand, 1920-1950 (Auckland: Auckland University Press, 2006), 66-82.

${ }^{14}$ James Cowan, "To Add Puke-taukere Chapter: The Swordsman in the Swamp: An Incident of the

Waitara War," undated typescript, Cowan Papers, 0039-42F, ATL; Cowan, New Zealand Wars, 2: 54; James Cowan, The Adventures of Kimble Bent: A Story of Wild Life in the New Zealand Bush (London: Whitcombe and Tombs, 1911), p. 61; Cowan, New Zealand Wars, 2: 209.

${ }^{15}$ Christopher Hilliard, "Licensed Native Interpreter: The Land Purchaser as Ethnographer in Early 20th-Century New Zealand," Journal of Pacific History 45, no. 2 (2010): 229-45.

${ }^{16}$ Ben Keys diary, 20 July 1920, Ben Keys Papers, MS-Papers-0407-32 (microfilmed as MS-Copy Micro-0724-4), ATL.

${ }^{17}$ David Colquhoun, "Cowan, James," http://www.teara.govt.nz/en/biographies/3c36/cowan-james (accessed 11 February 2014).

${ }^{18}$ Cowan to T. Lindsay Buick, "Sunday" (c. July 1937), T. Lindsay Buick Papers, MS-Papers-0058107, ATL.

${ }^{19}$ Cowan to E. H. McCormick, 12 December 1939, IA 1, 62/110/2, ANZ.

${ }^{20}$ Colquhoun, "Cowan."

${ }^{21}$ Cowan to P. J. Kelleher, 16 February 1924, IA 1, 4/2/13, ANZ.

${ }^{22}$ Cowan to James Hislop, 8 March 1918, IA 1, 4/2/13, ANZ.

${ }^{23}$ James Cowan, “The Urewera Campaigns: The Upper Whakatane-Colonel St John's Route," n.d., Cowan Papers, MS-Papers-0039-42C, ATL.

${ }^{24}$ PAColl-4306, ATL.

${ }^{25}$ Cowan to Hislop, 8 March 1918, IA 1, 4/2/13, ANZ.

${ }^{26}$ Cowan to Hislop, 8 March 1918, IA 1, 4/2/13, ANZ.

${ }^{27}$ T. W. Leys to G. W. Russell, 1 February 1918, IA 1, 4/2/13, ANZ.

${ }^{28}$ Cowan, New Zealand Wars, 1: xvi; A. H. Messenger, Children of the Forest: A Frontier Tale of Old Taranaki (Auckland: Blackwood and Janet Paul, 1966).

${ }^{29}$ Michael King, introduction to Cowan, New Zealand Wars, 1: 5; and see Cowan, New Zealand Wars, 1: 117.

${ }^{30}$ Cowan, "Old Race and the New."

${ }^{31}$ James Cowan, Suwarrow Gold: And Other Stories of the Great South Sea (London: Jonathon Cape, 1936), 7. The reviewer in the Times Literary Supplement picked up on the phrase: anon., "The

Schooner Men," Times Literary Supplement, 19 September 1936, clipping in Cowan Papers, MSPapers-0039-30, ATL.

${ }^{32}$ Cowan, unpublished typescript, n.d., 150, Cowan Papers, MS-Papers-0039-37, ATL.

${ }^{33}$ For a pretentious discussion of this impulse, see Chris Hilliard, "Textual Museums: Collection and Writing in History and Ethnology, 1900-1950," in Fragments: New Zealand Social and Cultural History, ed. Bronwyn Dalley and Bronwyn Labrum (Auckland: Auckland University Press, 2000), 118-39.

${ }^{34}$ J. Allan Thomson to Hislop, 1 December 1917, IA 1, 4/2/13, ANZ.

${ }^{35}$ Cowan, "Old Race and the New." On local historians, see Fiona Hamilton, "Pioneering History: Negotiating Pakeha Collective Memory in the Late Nineteenth and Early Twentieth Centuries," New Zealand Journal of History 36, no. 1 (2002): 66-81.

${ }^{36}$ James Cowan, “A Hauhau Warrior's Story: The Adventures of Peita Kotuku, Last Survivor of the 'Rifleman' Escapees (Notes taken by J. Cowan, 23/2/21)," Cowan Papers, MS-Papers-0039-41A, ATL.

${ }^{37}$ Cowan to Fildes, 28 December 1935, Fildes Papers, box 34, VUW.

${ }^{38}$ Cowan to T. W. Downes, 10 November 1937, Cowan Papers, MS-Papers-0039-05, ATL.

${ }^{39}$ For examples, see Jack Adrian, ed., Detective Stories from The Strand (Oxford: Oxford University Press, 1991); Adrian, ed., Strange Tales from The Strand (Oxford: Oxford University Press, 1991).

${ }^{40}$ Kennedy Williamson, Can You Write Magazine Stories? (London: Hutchinson, n.d.)

Journal of New Zealand Studies NS19 (2015), 28-39 
${ }^{41}$ Henry Matthew Stowell Papers, MS Papers-0062-28, ATL.

${ }^{42}$ Stevens to Stowell, 26 February 1930, Stowell Papers, MS-Papers-0062-22, ATL.

${ }^{43}$ Stevens to Stowell, 24 October 1932, Stowell Papers, MS-Papers-0062-22, ATL.

${ }^{44}$ Stephen Derek Hamilton, "New Zealand English Language Periodicals of Literary Interest Active 1920s-1960s" (PhD thesis, University of Auckland, 1996), 519-52; Hilliard, Bookmen's Dominion, pp. 44-46.

${ }^{45}$ Hall, "Mr Cowan's Survey," 8 September 1939, IA 1, 62/110/2, ANZ.

${ }^{46}$ Cowan to Oliver Duff, 1 December 1938, IA 1, 62/110/2, ANZ.

${ }^{47}$ Eileen Cowan to Eric Ramsden, 21 June 1944, Eric Ramsden Papers, MS-Papers-0196-191, ATL.

${ }^{48}$ Dennis McEldowney, "Publishing, Patronage, Literary Magazines," in The Oxford History of New Zealand Literature in English, ed. Terry Sturm, 2nd ed. (Auckland: Oxford University Press, 1998), 651.

${ }^{49}$ Colquhoun, "Cowan."

${ }^{50}$ Rachel Barrowman, "'Culture-organising': Joe Heenan and the Beginnings of State Patronage of the Arts," New Zealand Studies 5, no. 2 (1996): 4.

${ }^{51}$ The New Zealand Official Year-Book, 1935, section 35.

${ }^{52}$ Cowan to Hislop, 8 March 1918, IA 1, 4/2/13, ANZ.

${ }^{53}$ See Gregory Wood, "Revisiting James Cowan: A Reassessment of The New Zealand Wars (1922-

23)" (MPhil thesis, Massey University, Albany, 2010), 64.

${ }^{54}$ Cowan to Angus and Robertson, 30 May 1934, Cowan Papers, 39/30, ATL.

${ }^{55}$ Cowan, Suwarrow Gold, p. 7.

${ }^{56}$ Cowan to Lawlor, 16 May 1936, Patrick Anthony Lawlor Papers, 77-067-7/02, ATL.

57 "Suwarrow Gold," undated typescript (1936) prepared for Hicks Smith Wright, Cape's agents in Wellington, Cowan Papers, MS-Papers-0039-30, ATL. Cowan annotated his copy of the document to say that Mulgan wrote it.

${ }^{58}$ McEldowney, "Publishing, Patronage, Literary Magazines," 651.

${ }^{59}$ On the company at this time see Jason D. Ensor, Angus \& Robertson and the British Trade in Australian Books, 1930-1970: The Getting of Bookselling Wisdom (London: Anthem Press, 2012).

${ }^{60}$ James Cowan to Directors, Angus and Robertson, 18 March 1934, Cowan Papers, MS-Papers0039-30, ATL.

${ }^{61}$ W. T. Cousins to Cowan, 21 August 1934, Cowan Papers, MS-Papers-0039-30, ATL.

${ }^{62}$ Cowan to Cousins, 16 August 1938, Cowan Papers, MS-Papers-0039-30, ATL.

${ }^{63}$ Jonathan Cape to Cowan, 9 May 1935, Cowan Papers, MS-Papers-0039-30, ATL.

${ }^{64}$ Cowan to Cape, 20 December 1935, Cowan Papers, MS-Papers-0039-30, ATL.

${ }^{65}$ See clippings in Cowan Papers, MS-Papers-0039-30, ATL.

${ }^{66}$ Cape royalty statements, 31 December 1936, 30 June 1937, Cowan Papers, MS-Papers-0039-30, ATL.

${ }^{67}$ Cape royalty statements, 31 December 1937, 30 June 1938, 30 June 1939, 31 December 1939, 30 June 1940, Cowan Papers, MS-Papers-0039-30, ATL.

${ }^{68}$ On the institution of the "colonial edition," see Graeme Johanson, A Study of Colonial Editions in Australia, 1843-1972 (Wellington: Elibank Press, 2000); Richard Nile and David Walker, "The

'Paternoster Row Machine' and the Australian Book Trade, 1890-1945", in A History of the Book in Australia: A National Culture in a Colonised Market, ed. Martyn Lyons and John Arnold (St. Lucia: University of Queensland Press, 2001), 3-18, especially 8.

${ }^{69}$ Cape to Cowan, 21 August 1936, Cowan Papers, MS-Papers-0039-30, ATL.

${ }^{70}$ James Cowan, Wilde Südsee (Leipzig: Wilhelm Goldmann, 1938).

${ }^{71}$ Cashier, Jonathan Cape Ltd, to Cowan, 1 October 1937; Cowan to Jonathan Cape Ltd, 29 September 1937, Cowan Papers, MS-Papers-0039-30, ATL.

${ }^{72}$ Jan-Pieter Barbian, The Politics of Literature in Nazi Germany: Books in the Media Dictatorship, trans. Kate Sturge (2010; English trans. London: Bloomsbury, 2013), pp. 187-89.

73 "Wilhelm Goldmann Verlag in Leipzig," list of other published titles on unnumbered pages at the end of Cowan, Wilde Südsee.

${ }^{74}$ Cowan to Directors, Angus and Robertson, 18 March 1934, Cowan Papers, MS-Papers-0039-30, ATL.

Journal of New Zealand Studies NS19 (2015), 28-39 
${ }^{75}$ A. M. [Alan Mulgan], "Schooner Men: Old South Sea Days: Mr James Cowan's True Tales," Evening Post, 21 November 1936; anon., "The Schooner Men," Times Literary Supplement, 19 September 1936, clipping in Cowan Papers, MS-Papers-0039-30, ATL.

${ }^{76}$ Michael Billig, Banal Nationalism (London: Sage, 1995). My thinking here is indebted to John Baxendale, "'You and I-All of Us Ordinary People': Renegotiating 'Britishness' in Wartime," in "Millions like Us"? British Culture in the Second World War, ed. Nick Hayes and Jeff Hill (Liverpool: Liverpool University Press, 1999), 296. 